\title{
$104 \cdot 12 \cdot 877$
}

\section{UHIVERSITY OF CALIFORNIA, LOS ANGELES}

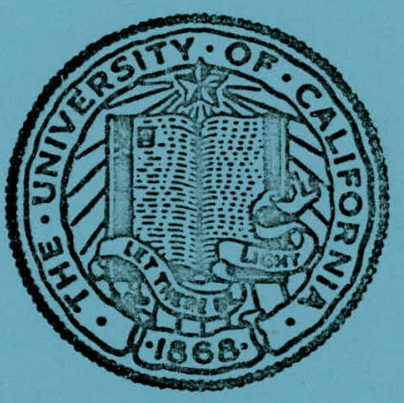

LABORATORY OF NUCLEAR MEDICINE AND RADIATION BIOLOGY CONTRACT NO. AT (04-1) GEN-12 


\section{DISCLAIMER}

This report was prepared as an account of work sponsored by an agency of the United States Government. Neither the United States Government nor any agency Thereof, nor any of their employees, makes any warranty, express or implied, or assumes any legal liability or responsibility for the accuracy, completeness, or usefulness of any information, apparatus, product, or process disclosed, or represents that its use would not infringe privately owned rights. Reference herein to any specific commercial product, process, or service by trade name, trademark, manufacturer, or otherwise does not necessarily constitute or imply its endorsement, recommendation, or favoring by the United States Government or any agency thereof. The views and opinions of authors expressed herein do not necessarily state or reflect those of the United States Government or any agency thereof. 


\section{DISCLAIMER}

Portions of this document may be illegible in electronic image products. Images are produced from the best available original document. 
PRODUCTION OF A NFRVOUS-SYSTEM-SPECIFIC

PROTEIN (14:3-2) BY HUMAN NEUROBLASTOMA

CELLS IN CULTURE

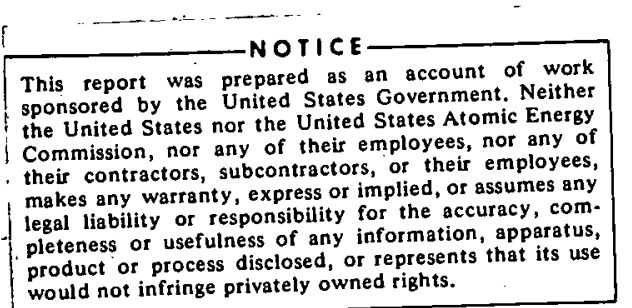

would not infringe privately owned rights. 
PRODUCTION OF A NERVOUS-SYSTEM-SPECIFIC

:PROTEIN (14-3-2) BY HUMAN NEUROBLASTOMA

CELLS IN CULTURE

-HARVEY -R:-HERSCHMAN \&

MICHAEL P. LERNER

LABORATORY OF NUCLEAR MEDICINE AND RADIATION BIOLOGY

900 VETERAN AVENUE

UNIVERSITY OF CALIFORNIA, LOS ANGELES, CALIFORNIA 90024 AND

DEPARTMENT OF BIOLOGICAL CHEMISTRY

UCIA SCHOOL OF MEDICINE; LOS ANGELES, CALIFORNIA 90024

Acknowledgement: These studies were supported in part by the Department of Biological Chemistry, Contract AT (04-1) GEN-12 between the Atomic Energy Commission and the University of California and by American Cancer Society Grant No. P-598. 
Cultured cell lines which continue to produce organ-specific products or exhlbit differentiated physiological characteristics have been established from neoplasms of a variety of tissues. Recently functional clonal

cell culture lines which produce the nervous-system-specific protein $s-100^{1,2}$ have been isolated from glial tumors ${ }^{3,4}$. These glial cultures have been extremely valuable in analyzing the regulation of accumulation of $5-100$ in growing cultures 5 , the synthesis and degradation of this protein ${ }^{6}$, and the regulation of several enzymes by hormones and neurotransmitters ${ }^{7}$.

Clonal cell lines derived from a spontaneously occurring mouse neuroblastoma, $\mathrm{C} 1300$, have also been isolated ${ }^{8-10}$. Many of these clones exhibit electrophysiological $1^{11-13}$, morphological ${ }^{14,15}$, and biochemical ${ }^{16-18}$ properties of neurons. Cell hybridization studies with $\mathrm{Cl} 300$ clones have lead to. a tentative model describing some aspects of neuronal differentiation 19,20 . Although several reports of the establishments of cell strains from human neuroblastomas exist ${ }^{21-23}$, such cells have not been extensively exploited for physiological and biochemical studies, in contrast to the mouse C1300 neuroblastoma clones. In this report we describe the production of a nervoussystem-spectfic protein, $14-3-2^{24}$, by the human neuroblastoma line IMR-32 22 . The purified 14-3-2 protein antigen was the generous gift of Dr. Blake Moore. Antisera to 14-3-2 were prepared in albino New Zealand female rabbits. Fach rabbit received three sets of toe pad and intradermal injections. Each injection, given at weekly intervals, contained $5 \mathrm{mg}$ of beef-brain 14-3-2 and $5 \mathrm{mg}$ of methylated bovine serum albumin in complete Freund's adjuvant. Three weeks after the last intradermal immunization a $5 \mathrm{mg}$ booster of 14-3-2 was given by ear-vein injection. The animals were bled from the ear on the 
sixth and seventh days after the boost. Microcomplement fixation ${ }^{25}$ titers $^{2}$ against the homologous antigen were $1: 1000$ and $1: 1200$.

F.xtracts of mouse tissues were used to demonstrate organ-specificity. A single precipitin line formed between mouse brain extracts and antisera to bovine 14-3-2 protein. No precipitin line formed with extracts of liver, kidney, spleen, or heart. Cross-reacting material in mouse brain was detectable ( $80 \%$ complement fixation at peak) at concentration of soluble protein as low as $1-2 \mu \mathrm{g} / \mathrm{m} 1$ with an antiserum dilution of $1: 350$ (homologous titer, 1:1000). No cross-reacting material could be detected by complement fixation in extracts of mouse liver, kidney, spleen, or heart at protein concentrations up to $1000 \mathrm{\mu g} / \mathrm{ml}$ (the highest tested). Serological demonstration of organ specificity of 14-3-2, first reported by Moore and Perez ${ }^{24}$, has thus been confirmed on independently prepared antisera.

The human cell line IMR-32 first isolated by Tumilowicz et al.; 22 , was obtained from the American Type Culture Collection, Rockville, Maryland. Mouse $\mathrm{C} 1300$ neuroblastoma clones $\mathrm{NB}-41^{8}$ and $N 18^{14}$, as well as HeLa cells are currently carried in our laboratory. All cells were grown on $100 \mathrm{~mm}$ Falcon tissue culture plates in Nutrient Mixture $F 10^{26}$ (Grand Island Biological) supplemented with $10 \%$ fetal calf serum, except N18, which was grown on Dulbucco's Modified Eagle's Medium (Grand Island Biological) containing 10\% fetal calf serum. Medium was changed twice weekly in most cases, except as noted. Cells were grown at $37^{\circ}$ in a $95 \%$ air $-5 \% \mathrm{CO}_{2}$ humidifled incubator. Cultures were passed by trypsinization $\left(0.1 \%\right.$ trypsin in Saline $\left.{ }^{27}\right)$. Cell number was determined by hemocytometer count; protein was measured by the method of rowry et al. 28 
Stationary phase IMR-32, HeLa, NB-41 and N18 cells were analyzed by microcomplement fixation for the presence of 14-3-2 protein. Heta cells were included as a control culture derived from a non-neural human tumor. An extensive complement fixation reaction between extracts of IMR-32 cells and antisera to beef-brain 14-3-2 protein is demonstrable (Fig. 1). At the same antiserum dilution there is only a slight reaction with the HeLa extract, occurring at a protein concentration 30 -fold greater than that of the IMR-32 neuroblastoma extract. Complement fixation reaction at such high concentrations of total-protein are difficult to interpret, and may well be due to nonspecific effects. The possible production of a small amount of this protein by cultured HeLa cells cannot be discounted at present, however. Cultured cells derived from a human neuronal tumor thus contain easily detectable amounts of 14-3-2 protein, while cells of a nonneuronal origin contain at best marginal levels of this antigen, in agreement with analysis of tissue extracts. Extracts of mouse neuroblastoma C1 300 clones $N 18$ and $N B-41$ do not react with antiserum to 14-3-2 protein at appropriate dilutions for the detection of mouse brain 14-3-2 protein.

In several cell culture systems the synthesis of an organ-specific protein does not occur while the cells are in exponential growth, but only after the culture has reached confluency. This type of regulatory phenomenon exists in the $\mathrm{C}_{6}$ glial cell line. Accumulation of S-100 protein does not occur in rapidly dividing cells. Only in confluent stationary phase cells does the amount of the S-100 protein increase ${ }^{5}$. To determine whether a similar regulatory phenomenon for the nervous system-specific protein 14-3-2 occurs in IMR-32 neuroblastoma cells, we measured the amount of this protein at various points in the growth curve. The doubling time of the cells was about 25 hours (Fig. 2). This time is somewhat faster than that originally described $^{22}$. In contrast to the results obtained for $s-100$ protein in $C_{6}$ 
cells, 14-3-2 appears to accumulate in growing IMR-32 cells. The amounts of 14-3-2 and total cell protein increase proportionally. The relative amount of this nervous system specific marker is constant in rapidly dividing and stationary phase IMR-32 cells. Cell division and production of 14-3-2 protein are clearly not mutually exclusive phenomena in IMR-32 neuroblastoma cells.

During the course of this work, Drs. M. Goldstein and B. Moore informed us of similar complement fixation results with IMR-32 cells and with NJB neuroblastoma cells, a strain isolated by $\mathrm{Dr}$. Goldstein. We have also demonstrated the presence of 14-3-2 protein by complement fixation in NJB cells generously provided by Dr. Goldstein.

This work was supported by Contract AT(04) Gen-12 between the Atomic Energy Commission and the Regents of the University of California and by American Cancer Society Grant No. P-598. We thank Mrs. Bella Konya for excellent technical assistance.

\author{
Harvey R. Herschman \\ Michael P. Lerner
}

Department of Biological Chemistry and

Laboratory of Nuclear Medicine

School of Medicine

University of California, Los Angeles.

Los Angeles, California 90024 


\section{REFERENCES}

1. Moore, B., and McGregor, D., J. Biol. Chem. 2401647 (1965).

2. Moore, B., Biochem. Biophys. Res. Commun. 19739 (1965).

3. Benda, P., Lightbody, L., Sato, G., Levine, L., and Sweet, W., Science $161370(1968)$.

4. Lightbody, J., Pfeiffer, S., Kornblith, P., and Herschman, H., J. Neurobiol.. 1411 (1970).

5. Pfeiffer, S., Herschman, H., Lightbody, J., and Sato, G., J. Cel1 Physio1. 75329 (1970).

6. Herschman, H., J. Biol. Chem. 2467569 (1971).

7. de Vellis, J., Inglish, D., and Galey, F., in Cellular Aspects of Neural Growth and Differentiation (Edited by D. Pease) 23 (U. of California Press, Berkeley, 1971).

8. Augusti-Tocco, G., and Sato, G., Proc. US. Nat. Acad. Sci. 64311 (1969).

9. Klebe, R., and Ruddle, F., J. Cell Biol., 43 69a (1969).

10. Schubert, D., Humphreys, S., Baroni, C., and Cohen, M., Proc. US Nat. Sci. 64316 (1969).

11. Nelson, P., Ruffner, W., and Nirenberg, M., Proc. US. Nat. Acad. Sci. 641004 (1969).

12. Harris, A., and Dennis, M., Science 167 1253(1970).

13. Harris, A., Heinemann, S., Schubert, D., and Tarikas, H., Nature 231 296 (1971).

14. Seeds, N., Gilman, A., Amano, T., and Nirenberg, M., Proc. US. Nat. Acad. Sc1. 66160 (1970).

15. Schubert, D., Humphreys, S., DeVitry, J., and Jacob, F., Devel. Biol. 25 514 (1971). 
16. Blume, A., Gilbert, F., Wilson, S., Farber, J., Rosenberg, R., and Nirenberg, M., Proc. US. Nat. Acad. Sci. 67786 (1970).

17. Kates, J., Winterton; R., and Schlessinger, K., Nature 229345 (1971).

18. Dawson, G., Kemp, S., Stoolmiller, A., and Dorfman, A., Biochem. Biophys. Res. Commun. 44687 (1972).

19. Minna, J., Nelson, P., Peacock, J., Glazer, D., and Nirenberg, M., Proc. US. Nat. Acad. Sci. 68234 (1971).

20. Minna, J., Glazer, D., and Nirenberg, M., Nature New Biol. 235225 (1972).

21. Goldstein, M., Burdman, J., and Journey, L., J. Nat. Canc. Inst. 32 165 (1964):

22. Tumllowicz, J., Nichols, W., Cholon, J., and Green, A., Canc. Res. 30 $2110(1970)$

23. Lyon, G., Canc. Res. 302521 (1970).

24. Moore, B.W. and Perez, V.J. In Physiological and Biochemical Aspects of Nervous Integration (Edited F.D. Carlson) Prentice Hall, Engelwood Cliffs, New Jersey (1968).

25. Levine, L. in Handbook of Experimental Immuochemistry (Edited by D.M. Weir) 707 (Blackwell Scientific Publications, Oxford, 1967 ).

26. Ham, R.G., Exp. Cel1 Res. 29515 (1963).

27. Puck, T.T., Cieciura, S., and Fisher, H., J. Exp. Med. 106145 (1951).

28. Lowry, O., Rosebrough, N., Farr, A., and Randa11, R., J. Biol. Chem. 193265 (1961). 
Fig. 1 Complement fixation reaction between antiserum to beef-brain 14-3-2 protein and extracts of IMR-32 and HeLa cells. Stationary monolayers were washed twice in $\operatorname{Tr}$ is $-\mathrm{HCl}$ buffer $(0.01 \mathrm{M}), \mathrm{pH} 7.4$, containing $0.15 \mathrm{M} \mathrm{NaCl}$. Cells from a single $100 \mathrm{~mm}$ plate were scraped with a rubber policeman into one $\mathrm{ml}$ of this buffer and frozen until assay. Cell suspensions were thawed and sonicated for two five-second intervals with a Bronwill Blosonic III Sonifier at an intensity setting of 30 , using a microprobe. The sonicated suspenston was centrifuged at $40,000 \mathrm{xg}$ for 10 minutes. Sonication solubilized approximately $70 \%$ of the total protein. Microcomplement fixation reactions were performed in a final volume of $1.2 \mathrm{ml}$, using a $1: 300$ dilution of antisera to beef-brain 14-3-2 protein (homologous titer, 1:1000). IMR-32 extract (0); Hela extract (0).

Fig. 2 Production of the nervous-system-specific protein 14-3-2 by the IMR32 neuroblastoma strain. Cells were grown in nutrient mixture F-10 in $100 \mathrm{~mm}$ Falcon plates. Medium was changed at 48 hour intervals. Cell number per plate (0) was determined by hemocytometer count of suspensions of trypsinized cells. At the times indicated plates for total protein and 14-3-2 protein analysis were harvested (as described in the legend to Fig. 1) and frozen. Total protein per plate (0) and 14-3-2 $C^{\prime}$ units per plate ( $(\square)$ were determined after all samples had been harvested. The latter value, used because of the serological cross-eaction between beef brain 14-3-2 protein and the heterologous antigen in IMR -32 cells, is defined as that amount of cross-reacting antigen in IMR-32 cells required to give $40 \%$ fixation in the antibody excess region of a complement fixation reaction with antiserum to beef-brain 14-3-2 protein used at a dilution of 1:280 (for homologous bovine 14-3-2 protein 
this value is $38 \mathrm{~m} \mu g)$. 14-3-2 $\mathrm{C}^{\prime}$ units per plate are calculated as [reciprocal of the dilution of IMR-32 cell extract required to give $40 \%$

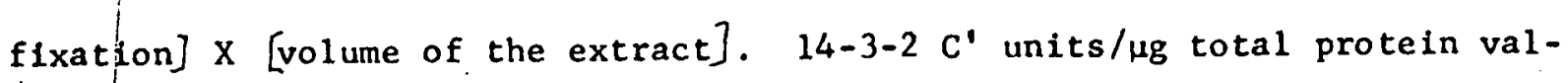
ues are illustrated by the filled squares. ( () . 


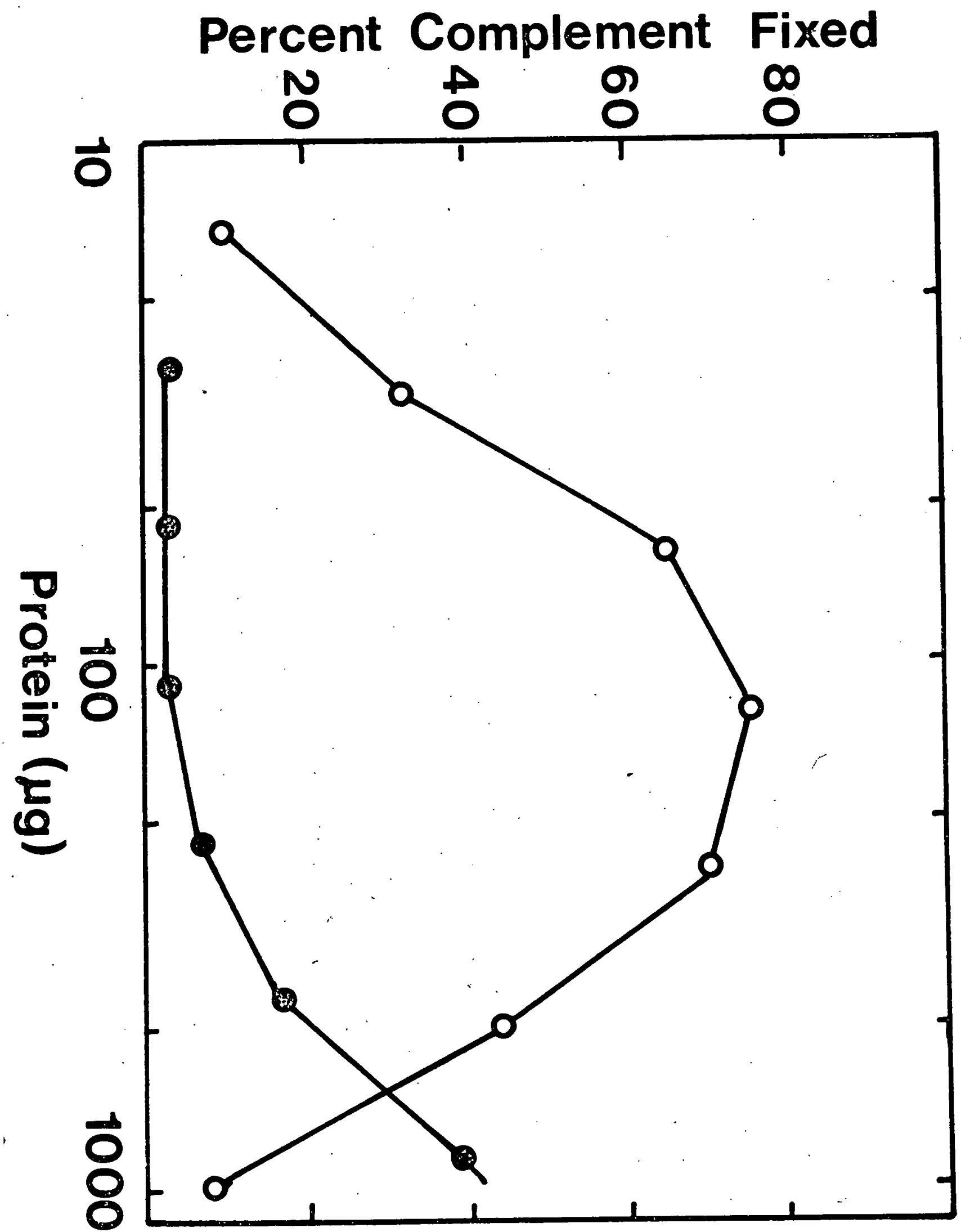




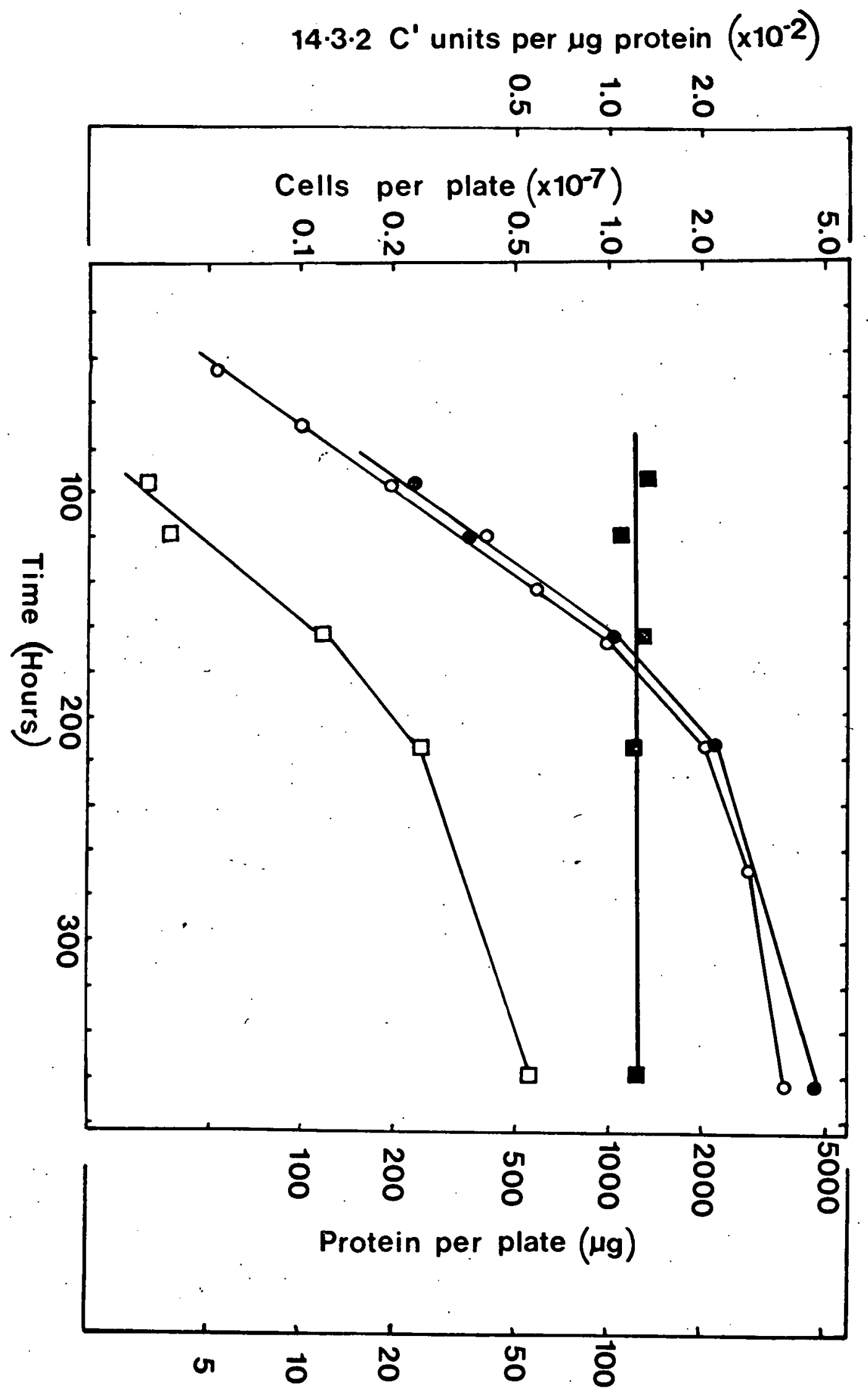

14.3.2 C' units per plate 
